\title{
Starvation Stress Induced Cardiac Diseases (Ssicds) and Activity of the Hepatic Enzymes: An Innovative Invention through Experimental Conditions
}

\author{
Mayadhar Barik* \\ Senior Scientific Advisor and Editor-in-Chief, India \\ Submission: May 05, 2018; Published: May 16, 2018 \\ "Corresponding author: Mayadhar Barik, Senior Scientific Advisor and Editor-in-Chief, Chairman-(ICOHAP-EM-2018), New Delhi-110029, India, \\ Email: mayadharbarik@gmail.com/barikmaya@gmail.com
}

\begin{abstract}
Introduction: Starvation or semi starvation diets for weight reduction in severely obese people have been reported of sudden death due to ventricular arrhythmias (Vas). Obesity is associated with cardiovascular diseases (CAD/CVD) and gastroenterology problem with hepatic disorders. Starvation including with the left ventricular hypertrophy (LVH) with prolongation of the QT interval, weight loss, the mass of the heart and left ventricle (LV) decreases. The exact signs of left ventricular dysfunction (LVD) are remain unclear. Effect of weight loss (EOWL), on the electrocardiogram (ECG) abnormalities of obesity appears to depend upon diet duration and upon whether protein and mineral nutritional status (MNS) is maintained and verified through different aspects of laboratory condition.
\end{abstract}

Material and methods: We chosen Channa fishes are easily available throughout the year. Cardiac tissues comprises of post mitotic tissues/ cells play a significant role in the organism. Biochemical parameters were chosen for the present study (1) soluble protein, (2) insoluble protein, (3) total protein, (4) percentage solubility of protein and (5) soluble/insoluble protein ratio. Earthen pots labeled as control (C), Experimental 1 (E1) and Experimental 2 (E2) were used. Fish kept in control pot served as control group and those in Experimental-1 served as 4 days starvation (4DS), Experimental-2 labeled as 7 days of starvation (7DS) and comparing with 10 DS and 15 DS. Experimental 3 labeled with food. Qualitative data was compared by applying chi-square test. The quantitative data represented as mean+SD was compared by applying one-way ANOVA followed by post hoc comparison in Bonferonni method. In this article, we evidenced that CR in nonhuman and humans has a positive effect on risk factors for CVD.

Results: While comparing the changes between 4 and 7 days after starvation, comparing with 10 days and 15 days we observed a significant decline in protein fractions in cardiac tissues of both sexes of the murrel in short term $(\mathrm{p}<0.05)$. Short term starvation and protein deficiencies may play important roles in promoting an electrically unstable heart. Stress, by eliciting autonomic imbalance, may act upon an electrically unstable heart to provoke acute arrhythmias in a subset of the obese population with QT interval prolongation.

Conclusion: CR improves several components of the metabolic syndrome and reducing the risk of CVD and alcoholic related complications (gastroenterology problem with hepatic disorders). Recent data and from this outcome bring out us the lesion that human subject at CR is likely to positive effects in humans healthy subject and alcoholic cardiac patients rather than the other animal model.

Keywords: Starvation; Stress; Cardiac diseases; Experimental conditions; Protein; Mineral nutritional status

\section{Introduction}

Presently the major risk factors for CVD/CAD are advancing age, obesity, intervention able to positively impact on both sexes of aging and obesity [1]. As of caloric restriction (CR) prove extremely useful in the fight against CVD [2]. TPC1 and TPC2 transcripts and protein levels paralleled the increase in autophagy identified by increased LC3-II and decreased p62 levels. siRNA depletion [3]. CR with in environmental or lifestyle intervention that has shown to increase the maximum life span and to retard aging in laboratory rodents for CAD/CVD
[4]. Starvation-selected lines (SSLs) does not exhibit excessive intracellular lipid deposition (EILD) within the myocardium and stored excess triglycerides in large lipid droplets within the fat body helps obesity-associated heart dysfunction (OAHD) [4]. Older hypothesis was challenged by David Barker who proposed that the intrauterine environment (IUE) influences the risk of non-communicable diseases (NCDs) [5]. MET successfully prevents DOX-induced cardiotoxicity in vivo by inhibiting DOXinduced oxidative stress (DOX-IOS), energy starvation (ES), depletion of intramitochondrial CoA-SH in the cellular level [6]. 


\section{Material and Methods}

\section{Study design}

We designed a prospective observational study. The study duration three years to verify the necessary parameters rely on very informative effect through caloric restriction.

\section{Sample collection}

Channa fishes are easily available throughout the year. Cardiac muscle and tissues comprise of post mitotic tissues/ cells play a significant role in the organism $d$ including with metabolism part.

\section{Sample processing}

Biochemical parameters were chosen for the present study

A. Soluble protein

B. Insoluble protein

C. Total protein

D. Percentage solubility of protein

E. Soluble/insoluble protein ratio. Earthen pots labeled as control (C), Experimental 1 (E1) and Experimental 2 (E2) were used for the study.

\section{Sample preservation}

Table 1: Test between sex group (Group 1, Group 2, and Group 3) frequency, column percentage with $\mathrm{x}^{2}$ test.

\begin{tabular}{|c|c|c|c|c|c|}
\hline Sl. No. & Group & Male & Female & Total & $\mathrm{p}$-value \\
\hline 1 & $1(\mathrm{C})$ & $9(37.50)$ & $6(31.58)$ & $15(34.88)$ & 0.92 \\
\hline 2 & $2(3 \mathrm{DS})$ & $7(29.17)$ & $6(31.58)$ & $13(30.23)$ & \\
\hline 3 & 3 (7DS) & $8(33.33)$ & $7(36.84)$ & $15(34.88)$ & \\
\hline 4 & 4 (10DS) & $7(30.12)$ & $5(30.14)$ & $12(30.75)$ & \\
\hline 5 & 5(15DS) & $8(33.33)$ & $7(36.84)$ & $15(34.88)$ & \\
\hline 6 & $4(\mathrm{TS})$ & $24.44(100)$ & $19(100)$ & $43(100)$ & \\
\hline
\end{tabular}

*Group 1 (Control group-C), Group 2 (3 days starvation-3DS), Group 3 (7 days starvation-7DS), Group 4 (total subject-TS), within sex group there is no significant changes observed.

Table 2: Effects of short term starvation and duration of sample storage on the measurement of cardiac amino acids in stress treated in different ways.

\begin{tabular}{|c|c|c|c|c|c|c|c|c|c|}
\hline $\begin{array}{l}\text { S. } \\
\text { No. }\end{array}$ & Parameter & Control (C) $(n=43)$ & $\begin{array}{l}\text { 4DS starvation } \\
\quad(n=43)\end{array}$ & $\begin{array}{l}\text { 7DS Starvation } \\
\quad(n=43)\end{array}$ & p-value & $\begin{array}{l}\text { Control (C) } \\
\text { and 4DS } \\
\text { Difference }\end{array}$ & $\begin{array}{l}\text { 4DS and } \\
\text { 7DS } \\
\text { Difference }\end{array}$ & $\begin{array}{l}\text { Results } \\
\text { in ( } \mathrm{S} \text { or } \\
\text { NS) }\end{array}$ & $\begin{array}{l}\text { Post hoc } \\
\text { Comparison }\end{array}$ \\
\hline 1 & $\begin{array}{l}\text { Length in } \\
\mathrm{cms}\end{array}$ & $13.33+1.8(15)$ & $13.02+0.9(13)$ & $15.04+0.89(15)$ & $<0.0001$ & $\begin{array}{c}-0.31 \\
(p=1.00)\end{array}$ & $\begin{array}{c}1.71 \\
(\mathrm{P}=0.002)\end{array}$ & S & 0.0001 \\
\hline 2 & $\begin{array}{l}\text { Weight in } \\
\text { gms }\end{array}$ & $22.13+4.06(15)$ & $13.02+3.88(15)$ & $27.46+4.95(15)$ & $<0.0001$ & $\begin{array}{c}-2.44 \\
(\mathrm{p}=0.439)\end{array}$ & $\begin{array}{c}5.33 \\
(\mathrm{P}=0.005)\end{array}$ & S & 0.0001 \\
\hline 3 & $\begin{array}{l}\text { Insoluble } \\
\text { protein }\end{array}$ & $\begin{array}{c}54.85+24.10 \\
77.76+51.09(13)\end{array}$ & $\begin{array}{c}46.02+3.88 \\
66.51+91.12 \\
(15)\end{array}$ & $\begin{array}{c}47.16+18.50 \\
55.99+46.66(11)\end{array}$ & $<0.5209$ & $\begin{array}{c}1.304 \\
(p=0.5211)\end{array}$ & $\begin{array}{c}1.304 \\
(\mathrm{P}=5209)\end{array}$ & NS & 0.5209 \\
\hline 4 & $\begin{array}{l}\text { Soluble } \\
\text { probein }\end{array}$ & $\begin{array}{c}94.56+35.59 \\
105.19+70.26(13)\end{array}$ & $\begin{array}{c}96.30+36.29 \\
95.41+74.59 \\
(13)\end{array}$ & $\begin{array}{c}92.92+25.74 \\
86.09+55.59(11)\end{array}$ & $<0.0001$ & $\begin{array}{c}0.398 \\
(p=0.8230)\end{array}$ & $\begin{array}{c}0.390 \\
(\mathrm{P}=8230 \\
(-) 12.72\end{array}$ & NS & 0.6498 \\
\hline
\end{tabular}




\section{Advanced Research in Gastroenterology \& Hepatology}

\begin{tabular}{|c|c|c|c|c|c|c|c|c|c|}
\hline 5 & $\begin{array}{l}\text { Total } \\
\text { protein }\end{array}$ & $\begin{array}{c}152.99+68.75 \\
169.07+98.56(13)\end{array}$ & $\begin{array}{c}187.80+90.14 \\
157.45+17.03 \\
(13)\end{array}$ & $\begin{array}{c}193.59+96.67 \\
147.67+10.74 \\
(11)\end{array}$ & $<0.0001$ & $\begin{array}{c}0.862 \\
(p=0.6498)\end{array}$ & $\begin{array}{c}0.862 \\
(p=0.6498)\end{array}$ & NS & 0.6498 \\
\hline 6 & $\begin{array}{l}\text { Percentage } \\
\text { of } \\
\text { solubility }\end{array}$ & $\begin{array}{c}74.02+44.23 \\
64.39+39.22(13)\end{array}$ & $\begin{array}{c}68.96+15.49 \\
62.77+28.64 \\
(13)\end{array}$ & $\begin{array}{c}60.08+30.51 \\
61.47+17.13(13)\end{array}$ & $<0.0005$ & $\begin{array}{c}-12.759 \\
(p=0.0005)\end{array}$ & $\begin{array}{c}-18.834 \\
(p=0.0005)\end{array}$ & S & -4.528 \\
\hline 7 & $\begin{array}{l}\text { Soluble/ } \\
\text { insoluble } \\
\text { ratio }\end{array}$ & $\begin{array}{c}23.56+0.117 \\
17.07+0.097(13)\end{array}$ & $\begin{array}{c}17.06+0.138 \\
16.95+1.20(13)\end{array}$ & $\begin{array}{c}15.60+0.200 \\
15.16+1.61(13)\end{array}$ & $<0.0005$ & $\begin{array}{c}-8.264 \\
(p=0.0005) \\
-10.716\end{array}$ & $\begin{array}{c}-3.382 \\
(p=0.0005)\end{array}$ & S & -3.382 \\
\hline
\end{tabular}

${ }^{*}$ Results are expressed in $\mathrm{mg} / \mathrm{g}$, tissue wet-weight, mean+SD

*Significantly different $(p<0.0005)$ vs freshly analyzed samples (ANOVA)

*Number in parentheses indicates sample size, NS: Not Significant; S: Significant

Table 3: Effects of long term starvation and duration of sample storage on the measurement of cardiac amino acids in stress treated in different ways.

\begin{tabular}{|c|c|c|c|c|c|c|c|c|c|}
\hline S. No. & Parameter & $\begin{array}{c}\text { Control (C) } \\
(n=43)\end{array}$ & $\begin{array}{c}\text { 10DS } \\
\text { Starvation } \\
(\mathrm{n}=43)\end{array}$ & $\begin{array}{c}\text { 15DS } \\
\text { Starvation } \\
(n=43)\end{array}$ & p-value & $\begin{array}{l}\text { Control (C) } \\
\text { and 10DS } \\
\text { Difference }\end{array}$ & $\begin{array}{c}\text { 10DS } \\
\text { and 15DS } \\
\text { Difference }\end{array}$ & $\begin{array}{c}\text { Results in } \\
\text { (S or NS) }\end{array}$ & $\begin{array}{l}\text { Post hoc } \\
\text { Comparison }\end{array}$ \\
\hline 1 & Length in $\mathrm{cms}$ & $\begin{array}{c}13.33+1.8 \\
(15)\end{array}$ & $\begin{array}{c}15.02+0.9 \\
(13)\end{array}$ & $\begin{array}{c}17.04+0.89 \\
(15)\end{array}$ & 1 & $\begin{array}{c}-0.31 \\
(\mathrm{p}=1.00)\end{array}$ & $\begin{array}{c}1.71 \\
(\mathrm{P}=1.00)\end{array}$ & NS & 1 \\
\hline 2 & Weight in gms & $\begin{array}{c}22.13+4.06 \\
(15)\end{array}$ & $\begin{array}{c}14.02+3.88 \\
(15)\end{array}$ & $\begin{array}{c}37.46+4.95 \\
(15)\end{array}$ & 1 & $\begin{array}{c}-2.44 \\
(\mathrm{p}=1.00)\end{array}$ & $\begin{array}{c}5.33 \\
(\mathrm{P}=1.00)\end{array}$ & NS & 1 \\
\hline 3 & $\begin{array}{l}\text { Insoluble } \\
\text { protein }\end{array}$ & $54.85+24.10$ & $42.02+3.88$ & $50.16+18.50$ & 1 & $\begin{array}{c}1.304 \\
(p=1.00)\end{array}$ & $\begin{array}{c}1.304 \\
(\mathrm{P}=1.00)\end{array}$ & NS & 1 \\
\hline 4 & $\begin{array}{l}\text { Soluble } \\
\text { probein }\end{array}$ & $94.56+35.59$ & $98.30+36.29$ & $94.92+25.74$ & 1 & $\begin{array}{c}0.398 \\
(p=1.00)\end{array}$ & $\begin{array}{c}0.390 \\
(\mathrm{P}=1.00\end{array}$ & NS & 1 \\
\hline 5 & Total protein & $152.99+68.75$ & $197.80+90.14$ & $197.59+96.67$ & 1 & $\begin{array}{c}0.862 \\
(\mathrm{p}=1.00)\end{array}$ & $\begin{array}{c}0.862 \\
(p=1.00)\end{array}$ & NS & 1 \\
\hline 6 & $\begin{array}{l}\text { Percentage of } \\
\text { solubility }\end{array}$ & $74.02+44.23$ & $76.96+15.49$ & $75.08+30.51$ & 1 & $\begin{array}{l}-12.759 \\
(p=1.00)\end{array}$ & $\begin{array}{l}-18.834 \\
(p=1.00)\end{array}$ & NS & 1 \\
\hline 7 & $\begin{array}{c}\text { Soluble/ } \\
\text { insoluble ratio }\end{array}$ & $23.56+0.117$ & $20.06+0.138$ & $18.60+0.200$ & 1 & $\begin{array}{c}-8.264 \\
(p=1.00)\end{array}$ & $\begin{array}{c}-3.382 \\
(p=1.00)\end{array}$ & NS & 1 \\
\hline
\end{tabular}

${ }^{*}$ Results are expressed in $\mathrm{mg} / \mathrm{g}$, tissue wet-weight, mean+SD

*Significantly different $(p<0.0005)$ vs freshly analyzed samples (ANOVA)

*Number in parentheses indicates sample size, NS: Not Significant; S: Significant

\section{Discussion}

Despite of recent advances in therapy the heart failure remains a major cause of mortality and morbidity. It is a growing healthcare burden worldwide. Alterations in myocardial energy substrate metabolism (MESM) are now occupied a hallmark of heart failure with CR improves several components of the metabolic syndrome and reducing the risk of CVD and alcoholic related complications (gastroenterology problem with hepatic disorders). Basically we are associated with an energy deficit (ED) in the failing heart. Metabolic shift mechanism (MSM) from mitochondrial oxidative metabolism (MOM) is the glycolysis had a significant correlation between ATP/ADP ratio and myocardial probucol level. The Cardio protective effect (CPE) of probucol in treatment of HF. An antioxidant properties enhancement of endogenous antioxidant reserve (mainly GPx) responsible for myocardial energy state level (MESL) [7]. Anorexia nervosa (AN) abnormalities of mitral valve motion (MVM) and reduced left ventricular mass (RLVM) associated with systolic dysfunction compared our earlier study [8].
Microsomal drug-metabolizing enzymes (MDMEs) is altered by several pathological or abnormal physiological states, such as changes in nutritional status, liver, heart or kidney diseases, hormonal disturbances, pregnancy, tumour-bearing state, adjuvant arthritis, changes in reticuloendothelial system and environmental factors related to stress, irradiation and heavy metals are the basic causal factors [9]. The activities of other metabolic pathways, such as glucuronidation, sulphate conjugation, acetylation and alcohol oxidation are generally affected to lesser extents (as per findings of the Length in $\mathrm{cms}$ and body wt in gms Table $2 \& 3$ ). Rats are the most commonly used in drug metabolism studies unlike fish (insoluble, soluble and total protein ratio) known that the activity of most of the microsomal drug-metabolizing enzymes (MDMEs) is more higher in males than in females through androgen action (AA) readily impaired the drug-metabolizing enzymes (DMEs) in male rats. Here we compared manifested by four mechanisms. The one is by impairment of androgen action (IOAA) and the other is by depression of the basic enzyme activity (DOBAA). Third is an 
effect of pathological states, observed only in male rats but not in females, Forth is generally not seen in other species of animals including with man.

Hence Table 1 we are unable to get significant (Group 1 (Control group-C), Group 2 (3 days starvation-3DS), Group 3 (7 days starvation-7DS), Group 4 (total subject-TS) p-value: 0.92 . Whereas the effects of starvation, hyperthyroidism, adrenal insufficiency, and diabetes and morphine administration are cases through DR changes occurred in metabolism are due to impairment of androgen action and pathological causes related to Length in cms, Weight in gms, Insoluble protein, Soluble probein and was observed p-value: 0.0001 . Whereas we got the values Total protein Percentage of solubility and Soluble/ insoluble ratios were lesser then p-value: 0.0005. Both attached in Table $2 \& 3$ as well. Drug-metabolizing enzymes (DMEs) showing sex differences are depressed more markedly in male fishes. Rather than those showing no clear sex difference ocuured in our study. We therefore recommend the use of female in the evaluation of the effects of pathological status on hepatic microsomal drugmetabolizing enzymes (HMDMEs) to be look forward in positive direction a home message from our study that animal also comparable unlike rat/fish and human experimentation and the excellence are quite useful [10].

\section{Basic Science to Clinical Application}

Generally, changes in activity of the hepatic enzymes reflect closely by the changes in the rates, fish of drug metabolism in vivo [11]. Because the protein-binding of drugs, hepatic blood flow and renal function. We are also known to affect the rate of drug metabolism and excretion in vivo and in vitro effect both [12]. The utility of starvation or semi starvation diets for weight reduction in severely obese people has been the reporting that of sudden death due to ventricular arrhythmias (Vas) with alcoholic cardiac patients (ACPs) [13]. Protein and mineral nutritional status (PAMNS) maintained by copper, potassium, lead, and magnesium deficiencies played roles in promoting an electrically unstable heart (EUH) [14]. Starvation stress eliciting autonomic imbalance (SSEAI) due to electrically unstable heart (EUH) to provoke acute arrhythmias. [15]. Hypertrophied and failing heart shifts (HTAFHSs) to ketone bodies as a significant fuel source for oxidative ATP production. The Specific metabolite biosignatures of in vivo cardiac ketonebodies utilization were is identified in proper way [16]. Future studies would be aimed at determining whether this fuel shift mechanism (FSM) is an adaptive or maladaptive significance for new therapeutic strategies on heart failure (HF) management of gastroenterological problems and hepatic dysfunction [16].

\section{Conclusion}

CR improves several components of the metabolic syndrome and reducing the risk of CVD and alcoholic related complications (gastroenterology problem with hepatic disorders). The lesion that human subject at CR is likely to positive effects in humans healthy subject and alcoholic cardiac patients with (gastroenterology problem with hepatic disorders).

\section{References}

1. García RV, Feijóo BS, Rodríguez PD, Mosquera LA, Assi AE, et al. (2016) Endolysosomal two-pore channels regulate autophagy in cardiomyocytes. J Physiol 594(11): 3061-3077.

2. Hardy CM, Birse RT, Wolf MJ, Yu L, Bodmer R, et al. (2015) Obesityassociated cardiac dysfunction in starvation-selected Drosophila melanogaster. Am J Physiol Regul Integr Comp Physiol 309(6): R658-R667.

3. Yajnik CS (2014) Transmission of obesity-adiposity and related disorders from the mother to the baby. Ann Nutr Metab 64(Suppl 1): 8-17.

4. Tesseromatis C, Alevizou A (2008) The role of the protein-binding on the mode of drug action as well the interactions with other drugs. Eur J Drug Metab Pharmacokinet 33(4): 225-230.

5. Kohlhaas M, Maack C (2011) Interplay of defective excitationcontraction coupling, energy starvation, and oxidative stress in heart failure. Trends Cardiovasc Med 21(3): 69-73.

6. Ashour AE, Sayed AMM, Abd-Allah AR, Korashy HM, Maayah ZH, et al. (2012) Metformin rescues the myocardium from doxorubicin-induced energy starvation and mitochondrial damage in rats. Oxid Med Cell Longev 2012: 434195.

7. El-Demerdash E, Awad AS, Taha RM, El-Hady AM, Sayed AMM (2005) Probucol attenuates oxidative stress and energy decline in isoproterenol-induced heart failure in rat. Pharmacol Res 51(4): 311318.

8. de Simone G, Scalfi L, Galderisi M, Celentano A, Di Biase G, et al. (1994) Cardiac abnormalities in young women with anorexia nervosa. $\mathrm{Br}$ Heart J 71(3): 287-292.

9. Kato R (1977) Drug metabolism under pathological and abnormal physiological states in animals and man. Xenobiotica 7(1-2): 25-92.

10. Fisler JS (1992) Cardiac effects of starvation and semistarvation diets: safety and mechanisms of action. Am J Clin Nutr 56(Suppl 1): 230S-234S.

11. Aubert G, Martin OJ, Horton JL, Lai L, Vega RB, et al. (2016) The failing heart relies on ketone bodies as a fuel. Circulation 133(8): 698-705.

12. Bedi KC, Snyder NW, Brandimarto J, Aziz M, Mesaros C, et al. (2016) Evidence for intramyocardial disruption of lipid metabolism and increased myocardial ketone utilization in advanced human heart failure. Circulation 133(8): 706-716.

13. Kolwicz SC, Airhart S, Tian R (2016) Ketones step to the plate: A game changer for metabolic remodeling in heart failure? Circulation 133(8): 689-691.

14. Horton JL, Martin OJ, Lai L, Riley NM, Richards AL, et al. (2016) Mitochondrial protein hyperacetylation in the failing heart. JCI Insight 2(1): e84897.

15. Fukushima A, Milner K, Gupta A, Lopaschuk GD (2015) Myocardial energy substrate metabolism in heart failure: from pathways to therapeutic targets. Curr Pharm Des 21(25): 3654-3664.

16. Scolletta S, Biagioli B (2010) Energetic myocardial metabolism and oxidative stress: let's make them our friends in the fight against heart failure. Biomed Pharmacother 64(3): 203-207. 


\section{Your next submission with JuniperPublishers will reach you the below assets}

- Quality Editorial service

- Swift Peer Review

- Reprints availability

- E-prints Service

- Manuscript Podcast for convenient understanding

- Global attainment for your research

- Manuscript accessibility in different formats

( Pdf, E-pub, Full Text, audio)

- Unceasing customer service

Track the below URL for one-step submission https://juniperpublishers.com/online-submission.php 